
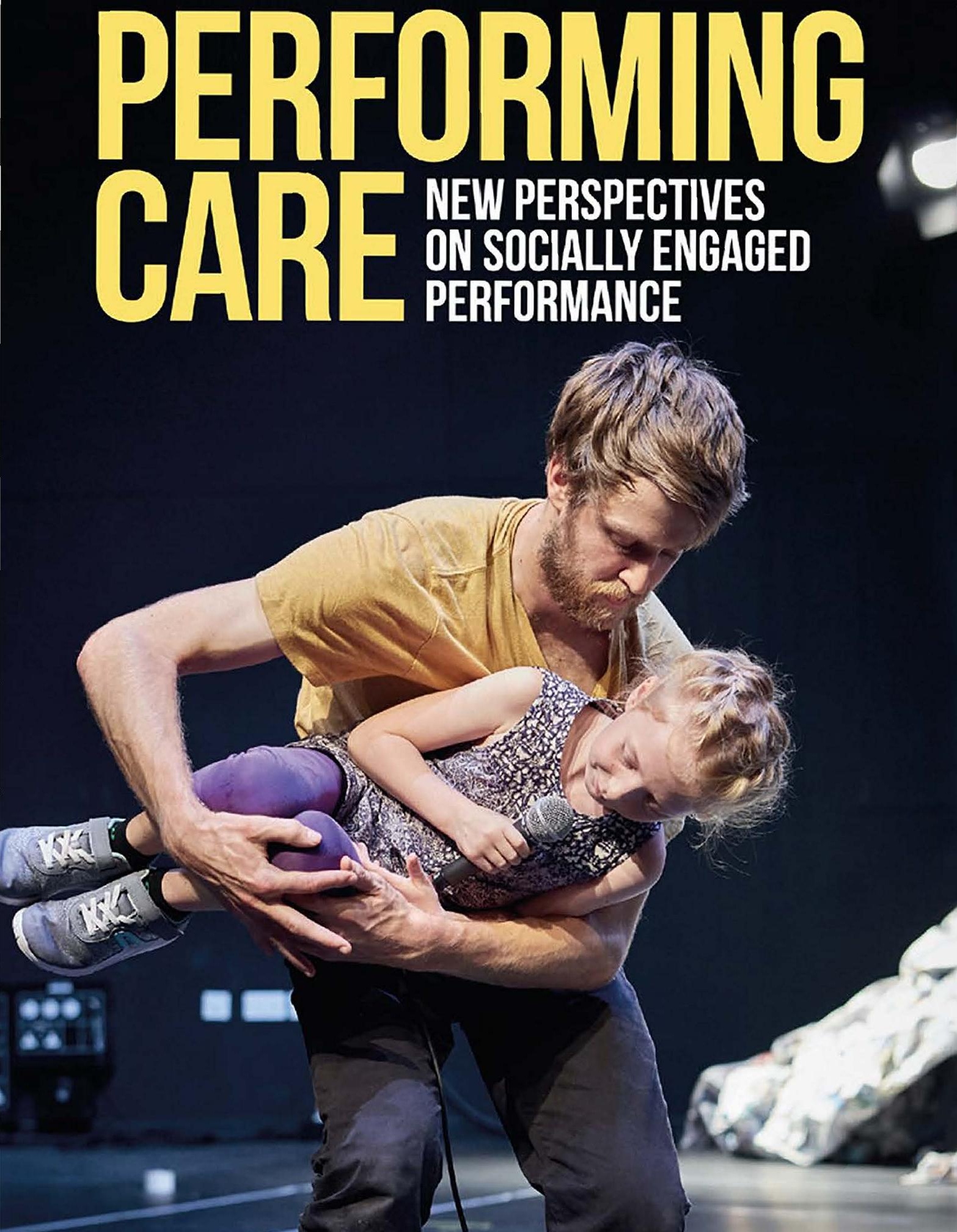

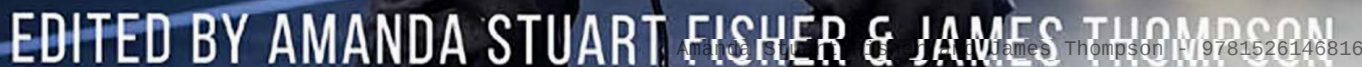




\section{Performing care}

\section{MANCHESTER 1824}

Manchester University Press 
Amanda Stuart Fisher and James Thompson - 9781526146816 Downloaded from manchesterhive.com at $04 / 26 / 2023$ 10:47:05AM 


\section{Performing care}

New perspectives on socially

engaged performance

\section{EDITED BY AMANDA STUART FISHER AND JAMES THOMPSON}

Manchester University Press 


\section{Copyright $\odot$ Manchester University Press 2020}

While copyright in the volume as a whole is vested in Manchester University Press, copyright in individual chapters belongs to their respective authors, and no chapter may be reproduced wholly or in part without the express permission in writing of both author and publisher.

This electronic version has been made freely available under a Creative Commons (CC-BY-NC-ND) licence which permits non-commercial use, distribution and reproduction provided the editors and Manchester University Press are fully cited and no modifications or adaptations are made. Details of the licence can be viewed at: https://creativecommons.org/ licenses/by-nc-nd/4.0/

Published by Manchester University Press

Altrincham Street, Manchester M1 7JA

www.manchesteruniversitypress.co.uk

British Library Cataloguing-in-Publication Data

A catalogue record for this book is available from the British Library

ISBN 9781526146809 hardback

ISBN 9781526146816 open access

First published 2020

The publisher has no responsibility for the persistence or accuracy of URLs for any external or third-party internet websites referred to in this book, and does not guarantee that any content on such websites is, or will remain, accurate or appropriate.

Cover: Photograph by Matthew Andrews

Typeset by Newgen Publishing UK 